\title{
Diurnal refuge sharing between species of Cuban snakes of the genus Tropi- dophis (Squamata: Tropidophiidae)
}

\author{
Javier Torres $^{1 *}(\mathbb{D})$ and Tomás M. Rodríguez-Cabrera² $\mathbb{D}$ \\ 'Department of Ecology and Evolutionary Biology, University of Kansas, Lawrence, Kansas 66045, USA. \\ ${ }^{2}$ Sociedad Cubana de Zoología, Cuba. \\ *Corresponding author (javiertorres@ku.edu)
}

Edited by: Robert W. Henderson. Date of publication: 14 May 2020.

Citation: Torres J, Rodríguez-Cabrera TM (2020) Diurnal refuge sharing between species of Cuban snakes of the genus Tropidophis (Squamata: Tropidophiidae). Caribbean Herpetology, 74, 1-2.

DOI: https://doi.org/10.31611/ch.74

Snakes of the genus Tropidophis Bibron, 1840 have undergone an adaptive radiation in Cuba, where 16 out of the 27 Antillean species occur (Hedges 2002). With this high diversity, coexistence of four species is somewhat common (Rodríguez et al. 2013). Coexistence has been hypothesized to be possible due to differences in habitat use based on body shape (Rodríguez-Cabrera et al. 2016). Even with potential segregating mechanisms, it is reasonable to expect certain levels of niche overlap. Herein we report three instances of diurnal refuge shared between species of Tropidophis.

We observed two instances of interspecific refuge sharing at "Lomas de Banao" Ecological Reserve, in Sancti Spiritus province $(21.8820,-79.5981 ; 560 \mathrm{~m}$ a.s.l.). On 18 September 2014, at $1330 \mathrm{~h}$, we found an adult female T. galacelidus and an adult female T. spiritus under the same rock (Fig. 1A). Nearby, we found another adult female T. galacelidus and an adult female T. melanurus under a rock. The rocks were piled up on an exposed trail, surrounded by mesophyllous evergreen forest. A closer examination of the snakes revealed that all were pregnant.

We observed a second instance of interspecific refuge sharing at El Nicho, in Cienfuegos province (22.0347, -80.1138; $440 \mathrm{~m}$ a.s.l.). On 30 October 2014, at 1035 h, we found an adult female T. galacelidus and an adult female T. semicinctus under the same rock (Fig. 1B). The rock was by a road in secondary grassland, completely exposed. The surrounding vegetation was mainly second-growth forests and isolated scrubs. A closer examination of the snakes revealed that they were pregnant.

A certain degree of interspecific tolerance can exist between species, especially when resources are limited (Begon 2006). At Lomas de Banao, there were many other potential refuges in the nearby forested areas, however, the snakes were only found at the few rock piles exposed to the sun. These individuals might have selected this limited refuge type for pregnancy-related thermoregulation. At El Nicho, rocky refuges were limited and the one where we found the snakes was the only one available in a radius of over 30 meters.

\section{Acknowledgments}

We thank Raimundo López-Silvero Martínez and Rosario Basail for field assistance and photographs.

\section{References}

Begon M, Townsend CR, Harper JL (2006) Ecology: from individuals to ecosystems (4th ed.). (Blackwell Pub., Malden, $M A)$.

Hedges SB (2002) Morphological variation and the definition of species in the snake genus Tropidophis (Serpentes, Tropidophiidae). Bulletin of the Natural History Museum, London (Zoology), 68, 83-90.

Hedges SB, Garrido OH (1992) A new species of Tropidophis from Cuba (Serpentes: Tropidophiidae). Copeia, 3 , 820-825. 
Rodríguez Schettino L, Mancina CA, Rivalta González V (2013) Reptiles of Cuba: Checklist and geographic distribution. Smithsonian Herpetological Information Service, 144, 1-96.

Rodríguez-Cabrera TM, Marrero R., Torres J (2016) An overview of the past, present, and future of the Cuban Boa, Chilabothrus angulifer (Squamata: Boidae): a top terrestrial predator on an oceanic island. IRCF Reptiles \& Amphibians, 23, 152-168.


Figure 1. Species of Tropes (Tropidophis) sharing diurnal refuges. (A) T. galacelidus and T. spiritus. Photo by Raimundo López-Silvero. (B) T. galacelidus and T. semicinctus. Photo by T.M. Rodríguez-Cabrera. 